\title{
Elikagaien paketatze aktiborako polimeroen gainazalaren aldaketa
}

\author{
(Polymer surface modification for active packaging \\ of food)
}

\author{
Jon Andrade del Olmo, Leyre Pérez Álvarez* \\ Kimika Makromolekularreko Laborategia, Kimika Fisikoa Saila, \\ Zientzia eta Teknologia Fakultatea (UPV/EHU) \\ *leyre.perez@ehu.es
}

DOI: $10.1387 /$ ekaia.17861

Laburpena: Paketatze-industrian jatorri petrokimikoa duten polimeroak ordezkatzeko, biopolimeroak gero eta gehiago erabiltzen dira. Poliazido laktikoaren L-isomeroak (PLLA) zink oxido ( $\mathrm{ZnO}$ ) nanopartikulekin nahastean, elikagai-industrian paketatzeko material moduan erabiltzeko ezaugarri onak aurkezten ditu. $\mathrm{ZnO}$ nanopartikulek bakterioen aurkako portaera erakusten dutela aipatzekoa da. Aktibitate antibakterianoa erakusten duten biopolimero asko daude, baina bakterioen aurkako aktibitaterik onena erakusten duena kitosanoa da. Lan honetan, beraz, PLLA-ZnO filmetan gainazalaren aldaketa gauzatuko da bakterioen aurkako ezaugarriak hobetzeko asmotan kitosanoa gainazalean txertatuz. Horretarako, lotura kobalente eta elkarrekintza elektrostatiko moduko zenbait metodo erabili dira, eta aldaketen lorpena eta garatutako filmen propietateak aztertu dira.

Hitz gakoak: Gainazalaren aldaketa, poliazido laktiko (PLA), kitosano.

Abstract: Nowadays biopolymers are replacing the polymers derived from petrochemicals for the packaging industry. Poly-L-isomer of lactic acid (PLLA), blended with $\mathrm{ZnO}$ nanoparticles, shows good properties as food packaging material. Among these beneficial features, it should be noted the antibacterial properties. There are a large number of polymers that present antibacterial capacity, but the best capacity is that of chitosan biopolymer. In this work, therefore, surfaces of PLLA-ZnO films were modified in order to improve their antibacterial properties. For this, different modification methods will be studied, such as covalent bonding and electrostatic interactions, and the success of these modifications, as well as the final properties of the films will be analyzed.

Keywords: Surface modification, polylactic acid (PLA), chitosan. 


\section{SARRERA}

Gizartearen eta ekonomiaren hedapenak polimeroen garapenean eta erabileran eragin handia izan du. Jatorri petrokimikoko plastikoak (polipropilenoa, PP; polietilen tereftalatoa, PET edo polietilenoa, PE) eguneroko bizitzan erabiltzen dira, batez ere paketatze-industrian. Material horiek propietate onuragarriak erakusten dituztenez (trakzioarekiko erresistentzia eta oxigenoaren aurkako propietate onak) eta ekonomikoki merkeak direnez, beren erabilera nahiko handia da, plastikoak lortzea oso prozesu errentagarria bihurtuz. Hala ere, plastiko horiek ingurumenerako arazo larriak erakusten dituzte, biodegradagarriak ez direlako [1].

Jatorri petrokimikoko polimeroen biodegradagarritasun eza arazo larria da. Izan ere, polimero horien erabilera amaitzen denean, zabortegietan metatzen dira [2,3]. Horretaz gain, jatorri petrokimikoa duten material horien biziraupena ingurumenean luzeegia da; beraz arazoari aurre egiteko irtenbide bat aurkitzea beharrezkoa da. Arazoa konpontzeko bi estrategia desberdindu daitezke: plastikoen birziklapena eta biopolimeroen sustapena.

Alde batetik, plastikoen birziklapen-prozesua nahiko zaila da. Izan ere, batzuetan zaila da plastikoen birziklapen zuzena egitea beste konposatuekin nahastuta dagoelako; besteetan, aldiz, ez dira ekonomikoki batere errentagarriak izaten.

Beste aldetik, bigarren estrategia biopolimeroen erabilpena sustatzean datza. «Biopolimero» hitza, orokorrean, polimero biodegradagarriez hitz egiteko erabiltzen da; hots, denbora-tarte zehatz batean, mikroorganismoen akzio katalitikoaren ondorioz molekula sinpleagotan (karbono dioxidoan, uretan edo metanoan) apurtzeko gai diren polimeroak dira. Gaur egun iturri naturaletatik edo «bioiturrietatik» eratorritako polimeroei ere biopolimero deritze, baina horiek ez dira zertan biodegradagarriak izan. Bioiturrietatik eratorritako polimeroez gain, biodegradagarriak direnak eta bien arteko konbinaketa betetzen dituztenak daude.

Azken ezaugarri hori betetzen duen biopolimeroa poliazido laktikoa (PLA) da, hau da, bioiturrietatik eratorria eta biodegradagarria den biopolimeroa da [4]. PLA jatorri petrokimikoko polimeroak ordezkatzeko erabil daiteke. Garatu diren teknika berriei esker, prezio baxuko eta pisu molekular altuko PLA ekoiztea lortu da, paketatze-industrian erabilera emanez [1].

Bioiturrietatik ekoiztutako PLA-ren bi isomero bereiz daitezke: $L$-isomeroa eta $D$-isomeroa. $L$-isomeroa frakzio ugariena da, iturri biologikoetatik eratorritako azido laktikoak forma hori aurkezten baitu. Gainera, $D$-isomeroak baino kristalinitate altuagoa du, propietate mekanikoak hobeak izanik. Beraz, PLA-ren $L$-isomeroak (1. irudia) erabilera interesgarriagoak izaten ditu [5]. 


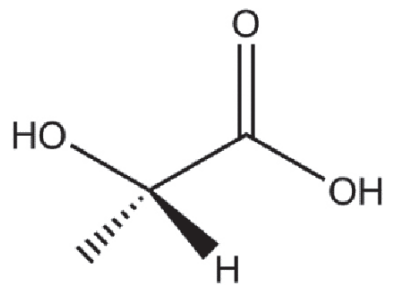

1. irudia. Azido $L$-laktikoaren egitura.

PLLA-k propietate fisiko-kimiko hauek aurkezten ditu: disolbagarria da disolbatzaile ez-polarretan, baina disolbagaitza disolbatzaile polarretan; egitura erdikristalinoa; $180^{\circ} \mathrm{C}$-ko fusio-tenperatura; $58^{\circ} \mathrm{C}$-ko beira-trantsizio tenperatura; $200^{\circ} \mathrm{C}$-ko degradazio-tenperatura eta 6-24 hilabeteko erdibizitza $37^{\circ} \mathrm{C}$-an. Propietate horiek tenperaturaren, ingurumenaren baldintzen, kristalinitate mailaren eta materialak jasan duen tratamenduaren arabera alda daitezke [6].

PLLA paketatze-industrian erabiltzen da gardena, ez-toxikoa eta ingurumenarekiko propietate ez-kutsakorrak izateagatik. Hala ere, ezaugarri desegokiak ere baditu: zurruntasun handia eta hidrofobotasuna. Azken ezaugarri horregatik, bakterioak gainazalera adsorbatzen dira, biofilmen (mikroosganismoen komunitateen) eraketa faboratuz [7]. Hori arazo larria da paketatze-industrian; izan ere, biofilmak elikagaiak paketatuta dauden gainazalean sortuko dira elikagaiak kutsatuz eta hondatuz, eta gaixotasun larriak sortaraziz [8].

Biofilmen eraketa bakterioen eta gainazalaren arteko elkarrekintza ezespezifikoen araberakoa da (indar elektrostatikoak, Van der Waals indarrak eta elkarrekintza hidrofoboak), non indartsuenetakoak elkarrekintza hidrofoboak diren [9]. Horren ondorioz, mikroorganismoak gainazal hidrofoboetan hidrofiloetan baino errazago itsasten dira [10,11]; beraz, gainazalaren hidrofobotasuna jaistea funtsezkoa da biofilmen eraketa murrizteko. Horrela, bada, biofilmen eraketa eta hedapena gainazalaren propietate fisikokimikoen mende egongo dira [7].

Biofilmen eraketa saihesteko, paketatzeko materialaren gainazala espezifikoki aldatzea paketatze aktiboa eratzeko mota bat da. Paketatze aktiboa elikagai, medikamentu edo beste produktuak paketatzeko erabiltzen da, non paketatzearen, produktuaren edota ingurumenaren arteko elkarrekintzak aldatzen diren produktuaren biziraupena luzatzeko, segurtasuna areagotzeko eta propietate sentsorialak hobetzeko, baina elikagaien eta medikamentuen kalitatea mantentzen da [12].

Gaur egun, bakterioen aurkako paketatze aktiboa, elikagaiak kutsatzen dituzten mikroorganismoen inhibizioan edo suntsipenean oinarritzen dena, 
oso garrantzitsua da. Mota horretako paketatze aktiboan, bakterioen aurkako ahalmena lortzeko, mikroorganismoen itsaspena saihestu edo itsatsitako mikroorganismoak suntsitu behar dira $[13,14]$.

Azaldutako estrategia horiek erabili ahal izateko, paketatzeko materialaren gainazalaren aldaketa gauzatzea barne-aldaketa gauzatzea baino bide aukeratuagoa da [6]. Gainazal- eta barne-aldaketen arteko desberdintasun nagusia da barne-aldaketan materialaren propietateak guztiz aldatzen direla eta aurrekoan ez, hau da, materialaren gainazal-propietateak soilik aldatzen dira gainontzeko materialaren ezaugarriak mantenduz.

Horregatik, gainazalaren aldaketa oso teknika aproposa da, aldaketa iraunkorrak eta eraginkorrak sortzen dituelako materiala eraldatu gabe. Gainazalen aldaketarako, metodo fisikoak eta kimikoak aurki daitezke. Metodo fisikoen artean plasma bidezko gainazalaren aldaketa aurki daiteke, baina hori ez da behin betiko aldaketa, denboran zehar gainazalak bere hasierako egoera berreskura dezakeelako [15]. Beste metodo fisiko bat monogeruza elektrostatikoa da [16], azken hori gainazalaren aldaketarako estrategia eraginkor eta sinple bat da. Dena den, metodo horrek lotura elektrostatikoak kanpoko $\mathrm{pH}$-aren eta indar ionikoaren aldaketen aurrean ez-egonkorrak direnaren desabantaila aurkezten du.

Metodo kimikoen kasuan, metodo horiek ere polimeroen gainazala funtzionalizatzeko erabiltzen dira. Hala ere, funtzionalizazio mota hori ez da errepikakorra eta zenbait propietate (pisu molekularra, kristalinitatea edo taktikotasuna) lortu ohi dira polimero berdinen artean [17]. Metodo kimiko horietan batez ere hidrolisi- eta aminolisi-erreakzioak egiten dira gainazal polimeriko geldoetan kimikoki aktiboak diren funtzio taldeak txertatzeko [18].

Paketatze-industriari dagokionez, bakterioen aurkako portaera oso garrantzitsua da eta estrategia desberdinak bilatzen ari dira materialen paketatzean bakterioen agerpena eta hazkundea ekiditeko. Estrategietako bat bakterioen itsaspena murriztean datza. Horretarako, azken urteotan nagusiki bi bide erabili dira: gainazalen hidrofilotasuna handitzea eta topografia aldatzea. Gainazalen hidrofilotasuna handitzea talde funtzional hidrofiloak txertatuz lor daiteke, bai metodo fisikoak, bai kimikoak erabiliz. Azken horien artean hidrolisi-erreakzioa oso erabilia izan da $-\mathrm{COOH}$ eta $-\mathrm{OH}$ taldeak gainazalean txertatzeko [19]. Gainazalaren topografia eta arkitektura, berriz, oso garrantzitsuak dira bakterioen itsaspenean, bakterioek gainazal leunetan itsasteko joera handia baitute. Horren arabera, bakterioen itsaspena murrizteko, gainazalaren morfologia alda daiteke gainazalean poroak edo nanoarkitekturak sortuz. Nahiz eta bakterioen gainazalaren topografiaren eragina asko ikertu den, gaur egun oraindik ez da efektu hori guztiz argitzea lortu, eta itxuraz kontrako emaitzak lortu dira, faktore anitzeko efektu aurrean aurkitzen garela islatzen duelarik. 
Elikagaien paketatze aktiborako polimeroen gainazalaren aldaketa

Halaber, bakterioen aurkako borrokan ikertzen ari den beste estrategia bat itsatsitako bakterioen suntsipena da. Bakterioak suntsitzeko ere ondorengo bi agente aurkitu dira: bakterioen aurkako nanopartikulak eta kontaktuan hiltzeko (ingelesez, contact killing) ahalmena duten molekulak.

Bakterioen aurkako agenteen artean, nanoegitura duten material ez-organikoen inguruko ikerketak ugaritu dira bakterioen aurkako aplikazioetarako. Nanopartikula horiek barne-aldaketa baten bidez polimeroetan erants daitezke, beren neurri koloidalagatik ondo dispertsatuak direlako eta materialaren oinarrizko propietaterik ez delako aldatzen. Izan ere, bakterioen aurkako ezaugarriez gain, nanopartikula askok propietate onuragarriak ematen dizkiote materialari paketatze-industrian erabiltzeko, hala nola, argi ultramorearen aurkako babesa elikagaia ez hondatzeko edota gardentasun ona elikagaiak ondo behatzeko plastikoan zehar [20], horiek dira, $\mathrm{ZnO}$ nanopartikulen gehikuntzarekin gertatzen diren hobekuntzak. Paketatze-industrian zilarra $(\mathrm{Ag})[21,22]$, kobrea $(\mathrm{Cu})$ [23] eta zink oxidoa $(\mathrm{ZnO})$ [24] erabiltzen dira, $\mathrm{ZnO}-\mathrm{a}$ erabiliena izanik. Izan ere, $\mathrm{ZnO}-\mathrm{a}$ ez da toxikoa, egonkortasun altua du presio eta tenperatura altuan eta ingurumenean ez du kutsadurarik sortzen [25]. ZnO nanopartikulak argi ultramorearekin eta ikuskorrarekin aktibatzen dira oxigenoaren espezie erreaktiboak emateko: $\mathrm{OH}^{-}-\mathrm{a}, \mathrm{H}_{2} \mathrm{O}_{2}$-a eta $\mathrm{O}_{2}{ }^{2-}$-a. Gaur egun, $\mathrm{ZnO}$ nanopartikulek eragindako bakterioen suntsipenerako mekanismoa oraindik oso argi ezagutzen ez bada ere, konposatu horiek bakterioen mintz zelularra kaltetzen dutela onartzen da $[24,26]$.

Aipatzekoak dira, halaber, bakterioen aurkako borrokan itsatsitako bakterioak suntsitzeko kontaktuan hiltzeko ahalmena duten molekulak [27]. Ahalmen hori erakusten duten molekulek bakterioen hilketa eragiten dute mintz zelularra desantolatuta. Amonio gatzak dituzten molekulek bakterioen mintz zelularrak kaltetzeko ahalmen berezi hori erakutsi dute. Alabaina, amonio taldearen karga positiboa eta negatiboki kargatutako bakterioaren mintz zelularraren buru fosfolipidoak lotzen dira eta horren ondorioz, mintz lipidikoak kaltetzen dira $\mathrm{K}^{+}$katioiak askatzen hasten direlako; hori dela eta, bakterioek osmoerregulazioa eta bestelako funtzio fisiologikoak galtzen dituzte. Ahalmen hori polikatioi batzuetan eta amonio gatzak edota amonio kuaternario taldeak dituzten gainazaletan aurkitu da, Gram positibo eta Gram negatibo bakterioak hiltzen dituztenetan. Polikatioien artean kitosano biopolimeroa da ezagunena [28].

Kitosanoa polisakarido lineal bat da eta bere kateetan ausaz kokatzen dira $\beta$-(1-4) $D$-glukosamina (deazetilatutako unitatea) eta $N$-azetil- $D$-glukosamina (azetilatutako unitatea) unitateak. Kitosanoak elikagaiak paketatzeko propietate egokiak ditu: ez-toxikoa, biodegradagarria, biobateragarria eta horretaz gain, mikrobio eta onddoen aurkako aktibitatea aurkezten duen konposatua da «kontaktuan hiltzea» ezaugarrian oinarriturik [28]. Gainera, dagoeneko kitosano filmak elikagaiak paketatzeko erabili dira eta emaitza 
positiboak lortu dira [29]. Beraz, esan daiteke kitosanoak, paketatzeko erabiltzen diren beste biomolekulekin konparatuta, bakterioen aurkako aktibitate hobea erakusten duela.

Gaur egungo ezagutza izan arren, bakterioen aurkako gainazal sintetiko eraginkorrak lortzeak itzelezko erronka izaten jarraitzen du. Horregatik, orain arte azaldutako estrategien efektu sinergikoaz baliatuta, zenbait konbinazio ikertu dira azken urteotan [16]. Ideia horren argitan, material biodegradagarrien diseinuan bakterioen aurkako zenbait estrategia aplika daitezke paketatze aktiborako propietate hobeak lortzeko. Ildo horretatik jarraituz, lan honetan egiten den proposamena bakterioen aurkako ezaugarriak gehituz PLLA polimero biodegradagarria hobetzea da. Horretarako, $\mathrm{ZnO}$ nanopartikulez PLLA-ren barne-aldaketa egin da eta lortutako substratuaren gainazala kitosano bakterioen aurkako biopolimeroarekin funtzionalizatu da. Lotura hori bide elektrostatikotik eta kobalentetik egin da. Horrela, polimeroen gainazalaren aldaketak aukera anitzak eskaintzen ditu etorkizun hurbileko elikagaien paketatze aktiborako materialak lortzeko.

\section{ATAL ESPERIMENTALA}

\subsection{Materialak}

Filmak lortzeko erabilitako PLLA-ren hornitzailea Purac Biochem (Herbehereak) izan zen eta $\mathrm{ZnO}$ nanopartikulen hornitzailea L'Urederra zentro teknologikoa (Espainia). PLLA eta $\mathrm{ZnO}$ nanopartikulak disolbatzeko, kloroformoa $\left(\mathrm{CHCl}_{3}\right.$, LAB-SCAN analytical sciences, \% 99) erabili zen eta ondoren, laginak hauspeatzeko, destilatutako metanola $(\mathrm{MeOH}$, Brenntag) erabili zen. Eratutako PLLA-ZnO filmen hidrolisirako erabilitako erreaktiboa sodio hidroxidoa $(\mathrm{NaOH}$, Panreac, \% 98) izan zen eta disolbatzaile bezala ur destilatua. Filmen garbiketarako, ur destilatua erabili zen. Kitosano disoluzioa pisu molekular altuko kitosanoarekin (Sigma-Aldrich, $>\% 75$ deazetilatuta, 310-375 kDa) egin zen eta disolbatzaile bezala $\%$ 1eko azido azetikoa (Sigma-Aldrich, \% 99) eta ur destilatua erabili ziren. Kolorimetrian, Laranja II sodio gatza (Sigma-Aldrich) koloratzailea erabili zen eta azido klorhidrikoa ( $\mathrm{HCl}$, Panreac, \% 37). Funtzionalizazio kobalentea egiteko, 1-etil-3-(3-dimetilaminopropil)karbodiimida (EDC, Sigma-Aldrich, \% 98) eta $N$-hidroxisukzinimida (NHS, Sigma-Aldrich, $\%$ 98) erabili ziren.

\subsection{Filmen prestaketa}

Laginak disolbatzaile-hauspeaketa prozesuaren bidez prestatu ziren, ondoren konpresioaren bidezko moldaketa eraginez. Lehenik eta behin, 
Elikagaien paketatze aktiborako polimeroen gainazalaren aldaketa

PLLA eta $\mathrm{ZnO}$ nanopartikulak banaturik $50 \mathrm{~mL}$ kloroformotan disolbatu ziren astintzailean 2 orduz, $300 \mathrm{~b} / \mathrm{m}$ utziz. Laginak ondo dispertsatzeko, sonikatzailean 380 segundoz utzi ziren eta ZnO nanopartikulak PLLA-rekin nahastu ziren pisutan \% 1eko nahastea lortuz. Ondoren, nahastea beste 380 segundoz sonikatzailean utzi zen ondo homogeneizatzeko.

Nahastea destilatutako metanol hotzean prezipitatu zen; horrek ziurtatzen du zink oxidoa polimeroaren matrizean modu homogeneoan banatzea. Lortutako materiala 48 orduz lehortu zen $70{ }^{\circ} \mathrm{C}$-ko labean. $100 \mu \mathrm{m}$ inguru zuten filmak ekoiztu ziren prentsa hidrauliko bero batean konpresioaren bidezko moldaketaren bidez. Laginak 4 minutuz $200{ }^{\circ} \mathrm{C}$-tan mantendu ziren $150 \mathrm{MPa}-k o$ presioarekin. Ondoren, filmak zuzenean ur-bainu batean hoztu ziren materialaren kristalinitatea ahalik eta baxuena izateko.

\subsection{Filmen gainazaleko aldaketa}

\subsubsection{Hidrolisia}

Lortutako PLLA-ZnO filmak $2 \times 2 \mathrm{~cm}^{2}$-ko zatitan moztu ziren. 3 aldi$\tan 20$ mL-ko metanol/ur (50:50) nahastean utzi ziren 25 minutuz filmak garbitzeko, eta 24 orduz lehortzen utzi ziren huts-sisteman $30^{\circ} \mathrm{C}$-an.

PLLA-ZnO filmen hidrolisia Lao et al.ek [30] garatutako prozesua egokituz burutu zen. Filmak $0,25 \mathrm{M} \mathrm{NaOH}-k o$ disoluzioan, $58^{\circ} \mathrm{C}$-an, 30 minutuz eta 200 b/m-ko abiadura konstantean murgildu ziren. Erreakzioa amaitutakoan, filmak ur destilatuan garbitu ziren 90 minutuz eta azkenik 24 orduz hutsean lehortzen utzi ziren.

\subsubsection{Funtzionalizazio kobalentea kitosanorekin}

Jadanik hidrolizatutako PLLA-ZnO filmen funtzionalizazio kobalentea Cui et al.-ek [31] garatutako prozesua egokituz burutu zen. $2 \times 2 \mathrm{~cm}^{2}-$ ko filmak $\mathrm{pH}$ 5eko tanpoi-disoluzioan murgildu eta gero, film bakoitzari $0,015 \mathrm{~g}$ NHS gehitu zitzaion. Behin NHS disolbatuta, film bakoitzaren gainean $0,025 \mathrm{~g}$ EDC gehitu eta gero, erreakzionarazten utzi ziren 4 orduz giro-tenperaturan, $250 \mathrm{~b} / \mathrm{m}$-ko irabiaketan.

Lau orduak pasa eta gero, filmak pH 5 duen tanpoi-disoluzio batez garbitu ziren, kitosano disoluzioan ( $2 \mathrm{~g} / \mathrm{L}$ ) murgildu ziren eta erreakzionarazten utzi ziren $40^{\circ} \mathrm{C}$-an 2 orduz, $250 \mathrm{~b} / \mathrm{m}$-ko irabiaketan. Erreakzioa amaitutakoan, 0,028 g EDC gehitu ziren eta 24 ordutan erreakzionarazi ziren giro-tenperaturan $200 \mathrm{~b} / \mathrm{m}$-ko abiaduran eta erreakzioa amaitutakoan, $\mathrm{pH}$ 5eko tanpoi-disoluzioarekin eta ur destilatuarekin garbitu ziren. Azkenik, huts-sisteman sartu ziren $30^{\circ} \mathrm{C}$-an egun batez funtzionalizatutako filmak guztiz lehortzeko. 


\subsubsection{Lotura elektrostatikoa kitosanorekin}

Hidrolizatutako PLLA-ZnO filmen eta kitosanoaren arteko lotura elektrostatikoa Del Hoyo-Gallego et al.ek [16] garatutako prozesura egokitua zen. Lehenik, $2 \times 2 \mathrm{~cm}^{2}$-ko filmak 3 orduz aktibatu ziren $0,1 \mathrm{M} \mathrm{NaOH}$ erabiliz, giro-tenperaturan, $200 \mathrm{~b} / \mathrm{m}$-ko irabiaketa konstante batez. Hiru orduak igaro eta gero, filmak kitosano disoluzioan ( $2 \mathrm{~g} / \mathrm{L})$ sartu ziren 24 orduz. Erreakzioa amaitutakoan, filmak ur destilatuarekin garbitu ziren eta lehortzen utzi ziren egun batez huts-sisteman.

\subsection{Karakterizazio-metodoak}

\subsubsection{Kolorimetria}

Filmen hidrolisian sortutako azido karboxiliko taldeen kuantifikazioa gauzatzeko TBO kolorimetria-metodoa erabili zen; hori Chollet et al.ek [32] garatutakotik egokitu zen. Metodoa Toluidine Blue-O koloratzaile kationikoaren eta hidrolisatutako PLLA-n sortutako talde azido desprotonatuen arteko lotura ionikoan oinarritzen da. Ondoren, prozesua laburki deskribatzen da. $5 \times 10^{-4}$ M-eko TBO disoluzioa prestatu zen $\mathrm{pH}$ 10 eko $\mathrm{NaOH}$ disoluzioarekin arrasean jarriz. Kolorimetria denbora desberdinetan hidrolizatutako PLLA-ZnO filmekin burutu zen eta horiek 5 minutuz murgilduta mantendu ziren koloratzailearen disoluzioan. Denbora hori pasatuta, $\mathrm{NaOH}$ disoluzioarekin garbitu ziren koloratzaile soberakina kentzeko. Filmetan lotutako koloratzailea \% 50 azido azetiko disoluzio urtsuarekin askatu zen. Erauzketan lortutako disoluzioen absorbantzia neurtu zen 633 nm-ko uhin-luzeran. Film bakoitzaren talde karboxilikoen kontzentrazioa lortzeko, $\left(\mathrm{A}=75301 \times \mathrm{M}(\mathrm{mol} / \mathrm{L}) r^{2}=0,9984\right)$ kalibratua erabili zen.

Gainera, kitosanoa txertatu ondoren modifikatutako PLLA-ZnO gainazalaren amino taldeen kuantifikazioa gauzatzeko metodo kolorimetrikoari jarraitu zitzaion Laranja II koloratzailearekin. Metodo hori Noel et al.ek [33] garatutakotik egokitua izan zen eta amino taldeen kuantifikazioa gauzatzeko erabiltzen da. Lehenik, 6 mL-ko 0,04 M den Laranja II-ko disoluzioa prestatu zen disolbatzaile bezala $\mathrm{pH} 3$ duen $\mathrm{HCl}-\mathrm{a}$ (\% 37) erabiliz. Gero, kitosanoz tratatutako filmak pisatu ziren eta 0,04 M den Laranja II 6 mL-ko disoluzioan sartu ziren. Koloratzailearen adsortzioa 30 minututan zehar $40^{\circ} \mathrm{C}$-an, $300 \mathrm{~b} / \mathrm{m}$-ko irabiaketarekin mantendu zen. Ondoren, laginak $\mathrm{HCl}-\mathrm{z}(\% 37)$ garbitu ziren $(6 \mathrm{~mL} \times 2)$. Azkenik, filmak $\mathrm{pH} 12$ duen $\mathrm{NaOH}$ disoluzioan $(6 \mathrm{~mL})$ sartu ziren eta hor, filmak lehenik adsorbitutako koloratzailea, minutu batean desorbatu zen, kolore horia hartuz. Lortutako disoluzioaren xurgapenak koloratzailearen erauzketan, $434 \mathrm{~nm}$ tan neurtu ziren SHIMADZU MultiSpec-1501 espektrofotometroan eta horrela, amino taldeen kuantifikazioa burutu zen. Erabilitako kalibrazioa $\lambda=434 \mathrm{~nm}$-an honako hau izan zen: y (xurgapena; $\mathrm{nm})=15.935,8 \times($ kontzentrazioa; mol/L) eta $r^{2}=0,9998$. 


\subsubsection{Kontaktu-angelua}

Metodo honek gainazal batek likido batez (urez) bustitzeko duen gaitasuna neurtzen du. Kontaktu-angelua: solido-likido eta likido-lurrun fasearteen elkargunean sortzen den angelua da. Gainazal solidoaren eta likidotanta baten arteko kontaktu-angelua hiru fasearteko tentsioen araberakoa da, Young ekuazioan ikus daitekeen bezala (1):

$$
0=\Upsilon_{\mathrm{SV}}-\Upsilon_{\mathrm{SL}}-\Upsilon_{\mathrm{LV}} \cos \theta_{\Upsilon}
$$

Non $\Upsilon_{S V}, \Upsilon_{S L}$ eta $\Upsilon_{L V}$ solido-lurrun, solido-likido eta likido-lurrun fasearteen gainazal tentsioak diren eta $\theta_{\Upsilon}$ kontaktu-angelua, 2. irudian ikus daitekeen moduan.

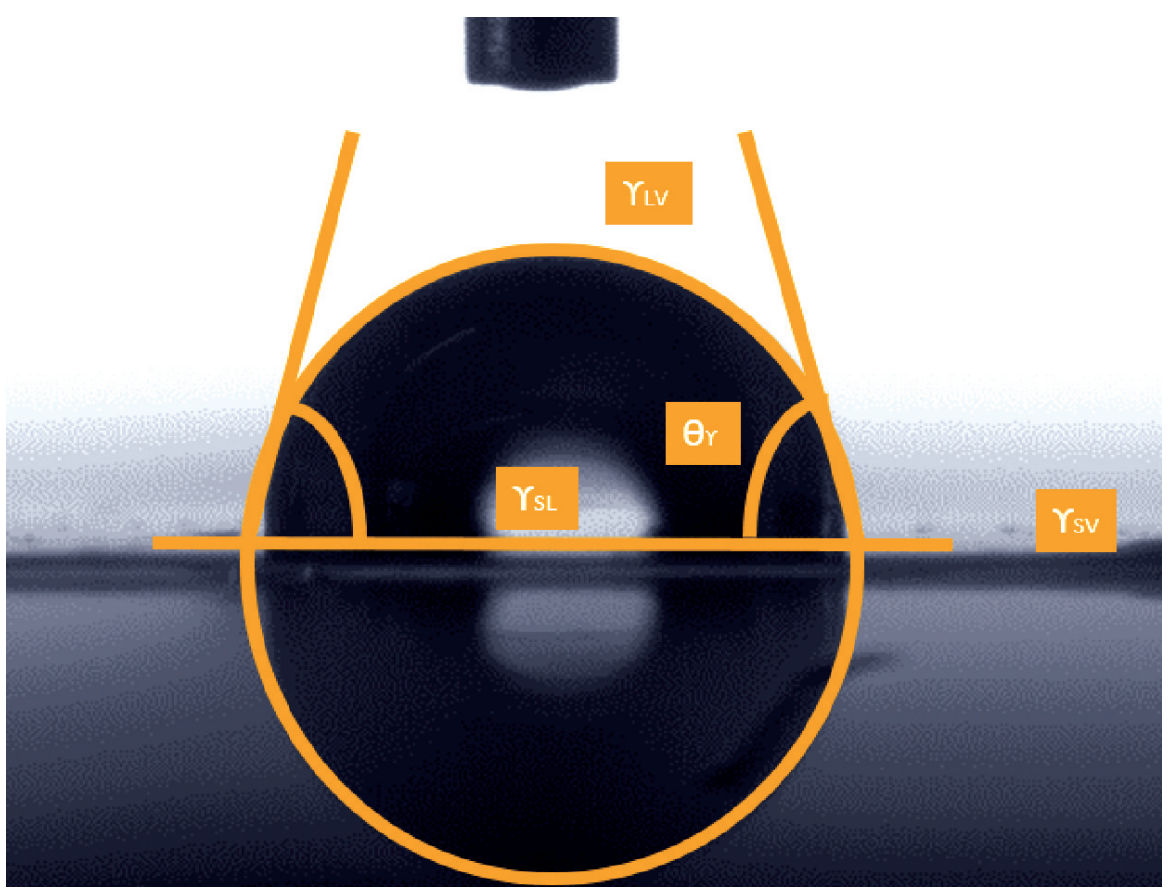

2. irudia. Kontaktu- angelua gainazal batean.

Teknika honetarako, gainazalera likido (ura) bolumen finko bat gehitzen da. Kontaktu-angelua $90^{\circ}$ baino txikiagoa denean, gainazala hidrofiloa dela esaten da, hau da, likidoak gainazala bustitzen duela. Kontaktu-angelua $90^{\circ}$ baino handiagoa denean, gainazal hidrofoboa izango dugu, gainazala ez delako likidoaz bustitzen [34]. 
Gainera, kontaktu-angelua asko aldatzen da gure materialaren topografiaren arabera; hala eta guztiz ere, metodo egokia, erraza eta sinplea da gainazalak bustitzeko duen ahalmena neurtzeko.

Hainbat filmen neurketa egin zen Beurtek Dataphysics OCA 15EC Instruments sistema optikoa erabiliz. Lagin bakoitzaren gainean, Milli-Q uraren 10 tanta ( $2 \mu \mathrm{L} /$ tanta) bota ziren eta kontaktu-angelua neurtu zen.

\subsubsection{Indar atomikoko mikroskopia (AFM)}

Analisi honek gainazalaren topografia zehatza eskaintzen du, hau da, laginaren gainazala arakatzean, bere topografia erregistratzen du konstanteki zunda baten bidez. Zunda hori hegal-labe bati lotuta dago eta horrela, gure gainazalaren erresoluzio handiko irudi bat lortzen da [35]. Gainazalaren altuera-aldaketak, detektagailuak neurtzen ditu islaturiko laserraren desbideraketaren arabera, eta horrela gainazal osoa eskaneatu eta gero, topografiaren irudia lortzen da, gainazalaren zimurtasuna $R_{a}$ (batez besteko zimurtasun) balioaz ezaugarrituz.

Filmen topografia neurtzeko, AFM Multimode 8 erabili zen Nanoscope V kontrolatzailearekin (Bruker). Saiakuntzarako erabili zen punta TESP-V2 motakoa izan zen, $7 \mathrm{~nm}$-ko erradioa zuena. Erabili zen erresonantzia-frekuentzia $320 \mathrm{kHz}$-ekoa izan zen eta malgukiaren indar-konstantea 37 N/m-koa. Gainazalaren topografia 1 Hz-eko eskaneatzeko abiadurarekin determinatu zen.

\section{EMAITZAK ETA EZTABAIDA}

\subsection{Filmen gainazalen aldaketa}

Funtzionalizazioa garatu ahal izateko ezinbestekoa izan da gainazalean talde aktiboak (karboxilo taldeak) txertatzea, eta hori PLLA-ren gainazalaren hidrolisi-erreakzioaz lortu da. Ondoren, gainazalean sortu diren gune aktibo horietan kitosanoa lot daiteke, nahi diren ezaugarri hobetuak emateko.

Gainazaleko karboxilo taldeen eta kitosanoaren arteko elkarrekintzak hainbat motatakoak izan daitezke: elkarrekintza elektrostatikoak eta lotura kobalenteak, besteak beste. Elikagaien paketatze aktiborako kasuan, lotura kobalenteak sortzea da gehien erabili den metodoa, elkarrekintza elektrostatikoan baino lotura sendoagoa sortu delako eta horrek elikagaietarako migrazioaren arriskua murrizten duelako [17]. Hala ere, gaur egun bi metodo horien eraginkortasuna eta egonkortasuna alderatzeko beharra dago. 
Elikagaien paketatze aktiborako polimeroen gainazalaren aldaketa

\subsubsection{Hidrolisia}

PLLA bezalako poliesterrak baldintza azidoetan eta basikoetan hidroliza daitezke. Esterren hidrolisi azidoa egiteko, hainbat mekanismo daude, onartuena oxigeno karbonilikoaren gaineko protoiaren eraso elektroizalea izanik. Hala ere, baldintza azidoak desegokiak dira gainazalaren aldaketa egiteko. Izan ere, esterrek ez dute hidrolisi elektroizalea ondo pairatzen, eta baldintza azido sendoak erabiltzean, hidrolisia ez da gainazalean gertatzen soilik, baizik eta material guztian zehar [36].

Hidrolisi basikoan, aldiz, hidroxidoen eraso nukleozalearen bidez ematen da elektroi dentsitate txikieneko zonaldean (karbono karbonilikoan) [36]. 3. irudian ikus daiteke hidrolisi basikoaren eskema. Hidroxidoak hidrolisi-erreakzioan zehar kontsumitzen dira eta gainazalean hidroxilo eta karboxilo taldeak eratzen dira. Hidroxilo talde horien eta solbatatutako hidroxido ioien arteko erakarpen elektrostatikoek $\mathrm{OH}^{-}$ioien difusioa murrizten dute materian zehar, gainazaleko hidrolisia faboratuz [37]. Beraz, PLLA-ZnO filmen hidrolisi basikoaren erreakzioa aurrera eraman da atal esperimentalean azaldutako baldintzetan.<smiles>COCC(=O)OC(C)C(=O)OCC(=O)OCC(=O)[OH2+]</smiles>

3.irudia. PLLA-ren gaineko hidrolisi basikoaren eskema.

PLLA-ZnO filmetan sortu diren karboxilo taldeen detekzioa eta kuantifikazioa TBO (toluidine blue) konposatuaren bidezko kolorimetriaz burutu zen. TBO metodo sinplea eta garrantzitsuena da, karboxilo taldeentzat espezifikoa dena. TBO koloratzailea konposatu kationikoa da zeinak negatiboki kargatutako taldeekin elkarrekintza elektrostatikoak sortzen dituen eta urdinaren zonaldean argi-absortzioaren bidez detektatzen den. Behin koloratzaile eta karboxilo taldeen arteko elkarrekintzak eratuta, filmetan geratutako koloratzaile kantitatea bolumen zehatz batean erauzten da, ondoren $630 \mathrm{~nm}$-tan espektroskopia ikuskorraren bidez karboxilo taldeen kopurua kuantifikatzeko. PLLA-ZnO filmetan sortu ziren karboxilo taldeen kontzentrazioa $2,76 \pm 0,39 \mathrm{nmol} / \mathrm{cm}^{2}$-koa izan zen.

\subsubsection{Funtzionalizazio kobalentea kitosanoarekin}

Erreakzioa gertatzeko, lehenik talde karboxilikoen aktibazioa aurrera eraman behar da ondoren, aldaketa kitosanoarekin egin ahal izateko amida sorreraren bitartez. Horretarako, beste konposatu batzuk gehitu behar dira, kasu honetan, EDC-a eta NHS-a. 
Karbodiimidak dituzten konposatuak, EDC bezalakoak, sarritan azido karboxilikoen aktibaziorako erabiltzen dira esterren edo amiden eraketa faboratzeko, erreaktibo nukleozale batekin erreakzionaraztean (adibidez, amina taldea). NHS bezalako gehigarriak botatzean aurreko ingurunera, NHS-ester egonkorragoa lortzen da. Horrela, albo-erreakzioak gertatzeko probabilitatea murrizten da eta azido taldeen aktibazioaren eraginkortasuna handitzen da [38]. Prego et al.ek [39] aurkitu zuten modu bat non EDC-a gehitzen den azido disoluziora NHS-aren presentzian, NHS konposatu aktibatuaren eraketa faboratuz eta aktibazioaren eraginkortasuna handituz. Hidrolizatutako PLLA-ZnO filmetan erabili den funtzionalizazio kobalentearen sekuentzia 4. irudiko eskeman laburtzen da.

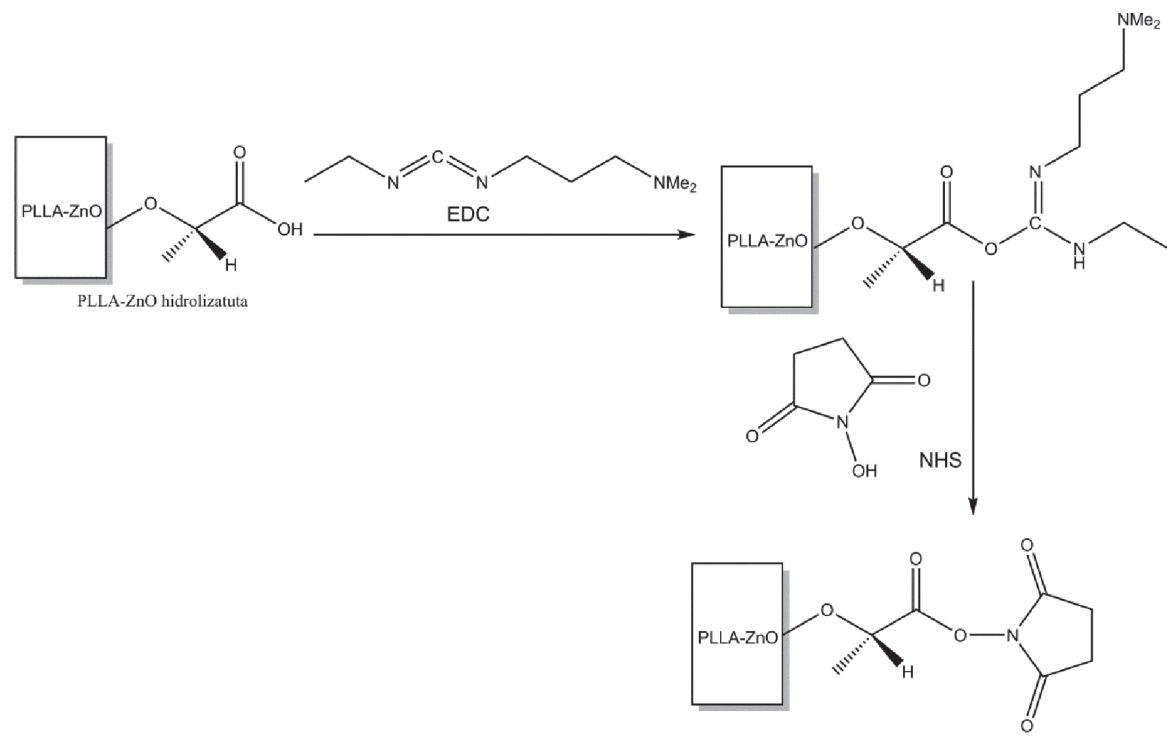

4. irudia. Talde karboxilikoen aktibazioa EDC eta NHS konposatuen presentzian.

Behin talde karboxilikoen aktibazioa lortuta, kitosanoarekin lotura kobalentea sor daiteke, kitosanoaren amino taldearen eraso nukleozalea gertatuz. Erreakzio horren eskema 5. irudian agertzen da.
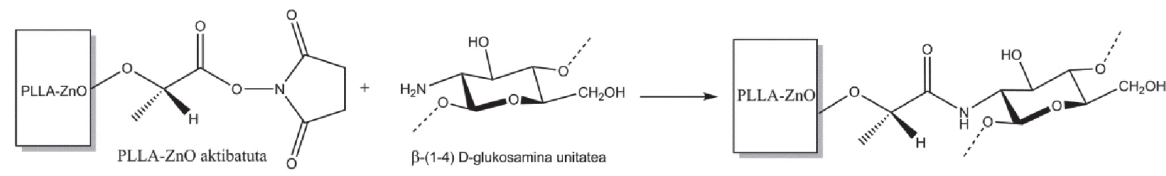

5. irudia. Funtzionalizazio kobalentearen erreakzio-eskema, kitosanoaren deazetilatutako egituraren zatiarekin. 
Elikagaien paketatze aktiborako polimeroen gainazalaren aldaketa

\subsubsection{Lotura elektrostatikoa kitosanoarekin}

Elkarrekintza elektrostatikoan, nahiz eta lotura ahulagoa den, beste estrategia eraginkorra da kitosanoa PLLA-rekin elkartzea [16]. Horrek hainbat abantaila ditu: sinplea, egiteko erraza eta eraginkorra, besteak beste. Elkarrekintza elektrostatikoaren eraginkortasuna karga kopuruaren mendekoa izaten da. Katioi eta anioi kopurua maximizatzeko, ionizazioa, eta beraz, $\mathrm{pH}$ egokia beharrezkoa da, bi espezieen $\mathrm{pK}_{\mathrm{a}}$-ren bitartekoa dena. Horregatik, kasu honetan kitosanoaren amino taldeen eta hidrolizatutako PLLA$\mathrm{ZnO}$ filmen azido karboxilikoen ionizazio egokia eratzeko, 5,6-ko pH-a hautatu zen. pH horretan, alde batetik, azido karboxiliko taldeak desprotonatzen dira karboxilato taldea sortaraziz eta bestetik, kitosanoaren amino taldeak protonatzen dira amonio katioia lortzeko. Behin kitosanoa eta azido karboxilikoa forma ionizatuan izanik, ioi-ioi elkarrekintzak sortzen dira (6. irudian). Ioi-ioi elkarrekintza horiek bereziak dira, polielektrolito baten kateetan eratzen direlako, kitosanoan zehar. Beraz, zenbat eta kitosanoaren pisu molekularra handiagoa izan, orduan eta sendoagoak izango dira elkarrekintzak. Aipatzekoa da pisu molekular handiko kitosanoa erabili dela lan honetan.

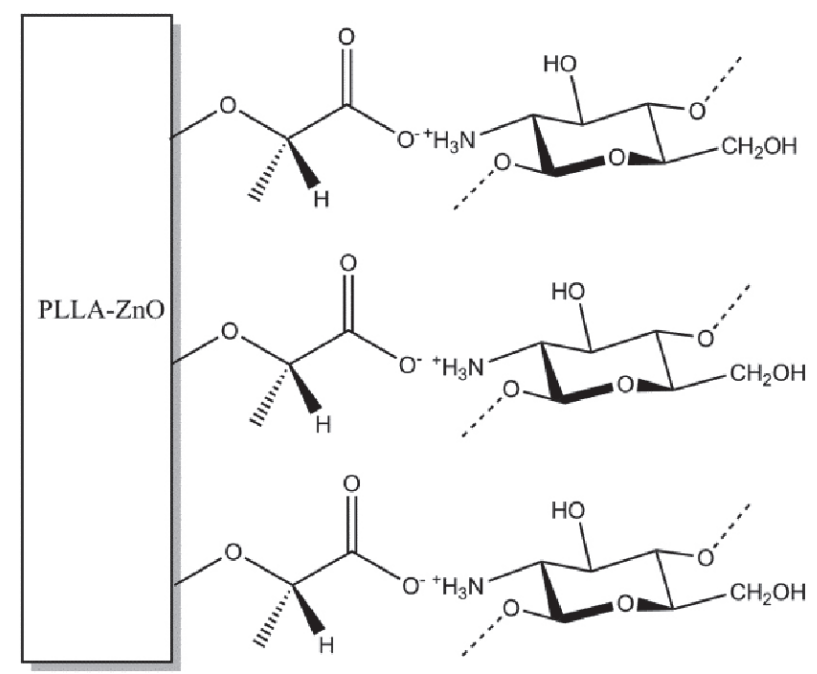

6. irudia. Monogeruza elektrostatikoaren irudikapena.

\subsection{Funtzionalizatutako gainazalen ezaugarritzea}

\subsubsection{Kolorimetria}

Laranja II kolorimetriaren bidez egindako determinazioek PLLA-ZnO filmen gainazal aldaketaren arrakasta frogatu zuten eta txertatzetik aurkez- 
ten diren kitosanoaren amino taldeen kuantifikazioa ahalbideratu zuten. Metodo hori koloratzailearen karga negatiboaren eta kitosanoaren karga positiboaren arteko elkarrekintza elektrostatiko itzulgarrietan oinarrituta dago. Baldintza alkalinoetan $(\mathrm{pH}=12)$, amino taldeak neutralizatu ondoren, lotutako Laranja II koloratzailea disoluziora askatzen da eta horrela, disoluzioaren xurgapena neurtzen da. Beraz, desorbitutako Laranja II koloratzailearen kantitatearen bitartez, amino taldeen kuantifikazioa burutu zen. Laranja II metodoa, koloratzailearen karga negatibo bakarragatik eta eragozpen esteriko baxuagatik, gainazaleko amino taldeen kuantifikaziorako oso sentikorra, selektiboa eta fidagarria izateagatik ezagutzen da [33].

Hasierako hidrolizatu gabeko eta hidrolizatutako filmei atxikirik amino talderik ez dagoela behatu da aztertutako lagin guztietan, adsortzioaren ondoren kolore gabeko filmak eta desortzio-disoluzio gardenak lortuz, 7. irudian ikusten den bezala. Beraz, kitosanorik gabeko aldaketen emaitza horiek substratu horretarako metodo kolorimetriko hori balioesten dute, eta adsortzio ez selektiboaren hipotesia arbuiatzen dute. Kitosanoarekin garatutako loturen kasuetan, berriz, bai kobalenteki, bai elektrostatikoki koloratzailea filmetan adsorbatzen da eta disoluzio basikoetan desorbitzen da horiek kolore laranja hartuz (7. irudia). Filmen gainazalean amino taldeen kontzentrazio parekoak determinatu dira bi aldaketa metodoetatik, 2,5$3,0 \mu \mathrm{mol} / \mathrm{g}$. Beraz, amino taldeak (kitosano) PLLA-ZnO filmei atxikita daudela ondoriozta daiteke eta funtzionalizazio kobalentea eta elektrostatikoa prozedura onak direla kitosanoa PLLA-ZnO filmetara lotzeko.

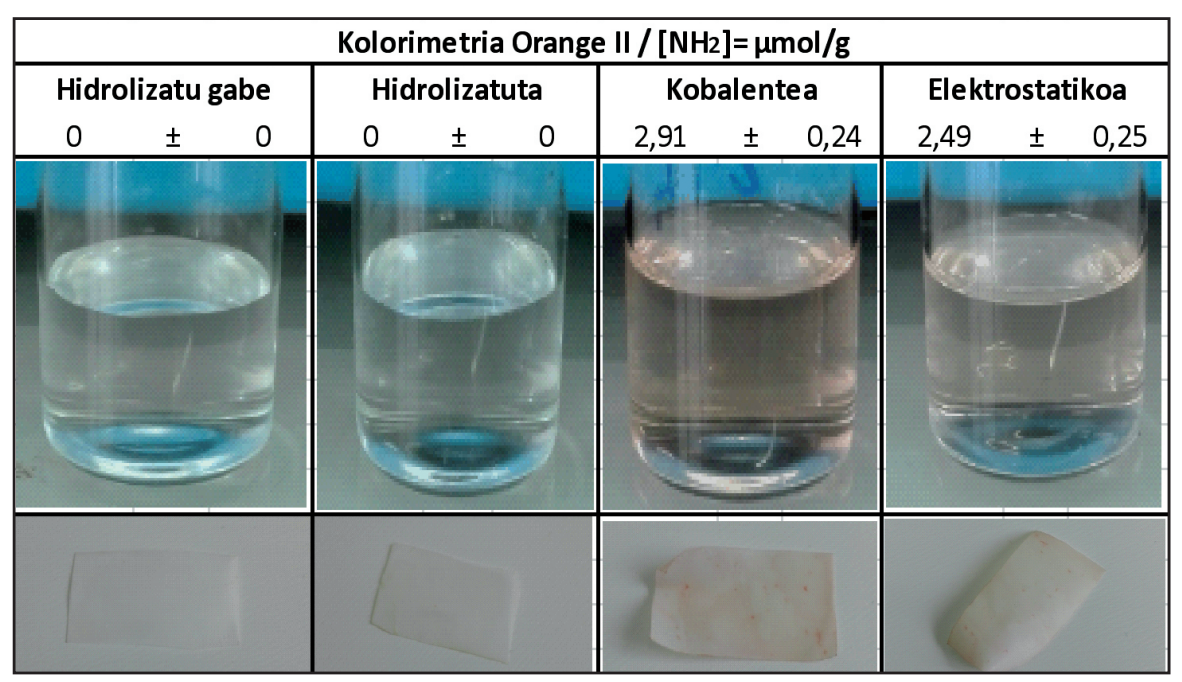

7. irudia. Orange II kolorimetria metodoaren bidez PLLA-ZnO laginen amino taldeen kuantifikazioa, filmetan gauzatutako koloratzailearen adsortzio eta desortziorako disoluzio basikoen argazkiak. 


\subsubsection{Kontaktu-angelua}

Aldaketarik gabeko eta aldaketa desberdinak (hidrolisia, funtzionalizazio kobalentea eta monogeruza elektrostatikoa) burutu ondoren, PLLA-ZnO filmen kontaktu-angeluaren aldakuntza aztertu zen. Aldaketa desberdinak jaso dituzten filmen kontaktu-angeluak 8. irudian erakusten dira, non ikus daitezkeen kontaktu-angeluaren jaitsiera bat PLLA-ZnO filmak hidrolizatzean eta ukipen-angeluaren igoera txiki bat PLLA-ZnO gainazal hidrolizatuak kitosanora lotzean.

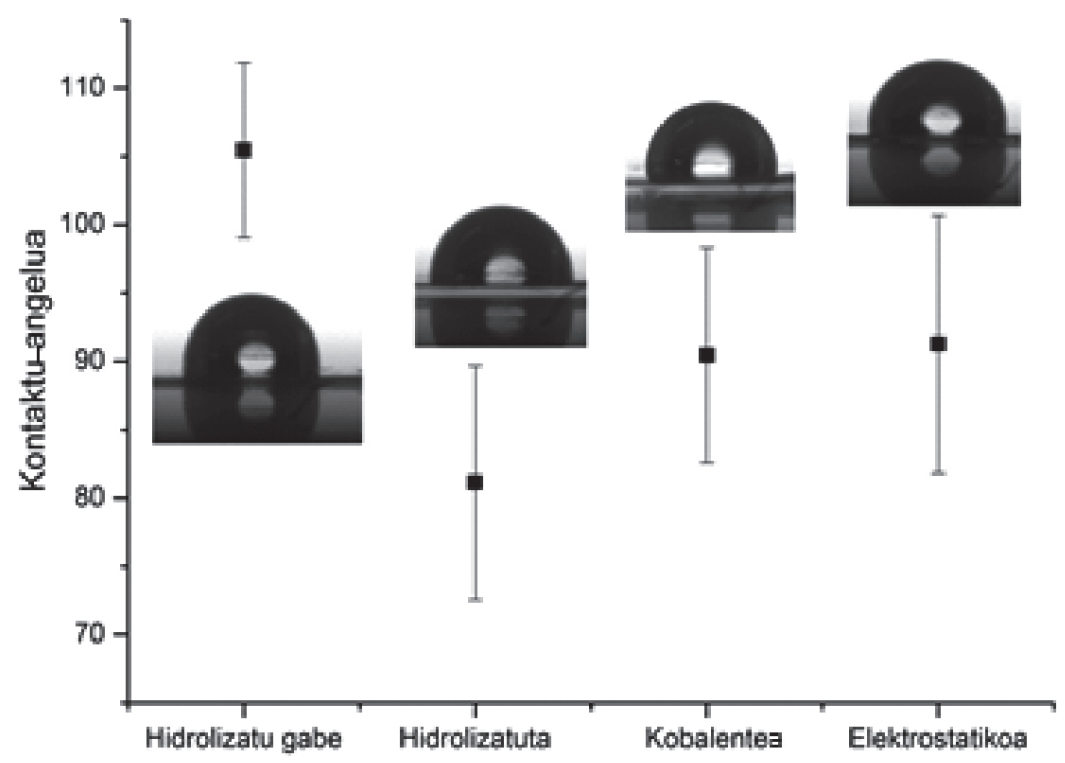

8. irudia. Kontaktu-angeluen balioak gainazalaren modifikazio desberdinetarako.

PLLA-ZnO filma hidrofoboa da, eta hori neurtutako kontaktu-angeluak, $\theta>90^{\circ}$, adierazten du. Hala ere, hidrolisi-erreakzioan eratutako azido karboxiliko eta hidroxilo taldeen ondorioz, gainazala hidrofiloago bihurtzen da, kontaktu-angeluaren jaitsiera behatuz. Beste aldetik, kitosanoa konposatu hidrofoboa da, ingurune oso espezifiko batzuetan soilik disolbatzen dena (ingurune azidoetan), eta horrek hidrolizatutako PLLA-ZnO laginen kitosanoarekiko gainazalaren aldaketak eragindako kontaktu-angeluaren igoera azaltzen du, bai funtzionalizazio kobalentearen, bai lotura elektrostatikoen bidez. Hala ere, kitosano/PLLA/ZnO filmen kontaktu-angelua hasierako PLLA-ZnO filmarekin alderatuta, txikiagoa da, hau da, burututako aldaketan gainazala hidrofiloagoak lortu dira. PLLA-ZnO filmaren gainazalaren hidrofilotasuna handitzearen ondorioz, materialak bak- 
terioen aurkako ahalmena handitzen du. Hau da, gainazalean bakterioen itsaspena murriztuko da, elkarrekintza hidrofoboak saihesten direlako, kitosanoaren eta $\mathrm{ZnO}$ nanopartikulen bakterioen aurkako portaeraz gain.

Dena den, aurrean aipatu den bezala, gainazalen kontaktu-angeluek gainazalaren topografiaren mendekotasun altua aurkezten dute. Beraz, kontaktu-angeluan behatutako aldaketa horiek gainazalaren zimurtasunaren aldaketak direla eta sortu izanak ahal dira. Horregatik, efektu hori ere aztertzeko, indar atomikoko espektroskopiaz gainazalen topografia aztertu zen.

\subsubsection{Indar atomikoko mikroskopia (AFM)}

Teknika honen bidez gainazalaren aldaketa bakoitzaren eraldatutako topografia aztertu zen. 9. irudian ikusten den bezala hidrolizatu gabeko filmetan gainazalak lauak dira eta batez besteko zimurtasun faktorea, $\mathrm{R}_{\mathrm{a}}$, nahiko txikia da, $<12 \mathrm{~nm}$. Hidrolisi-erreakzioak materialaren gainazalaren morfologia eraldatzen du barrunbe/poro txiki batzuk agertzen direlarik, $\mathrm{R}_{\mathrm{a}}$ handituz. Hidrolisi-erreakzioa 30 minutukoa denez, poro horiek gainazalean soilik sortzen dira eta ez materialaren barnean, irudietan ikus daitekeen bezala. Gainera, hidrolizatutako filmaren AFM irudian ikus daiteke hidrolisia ez dela homogeneoki gertatu material osoan zehar, hidrolizatu gabeko eta hidrolizatutako zonaldeak ondo bereizten baitira.

Kitosanoarekiko aldaketak burutu ostean, kitosano kateen presentzia bereiztu ahal da lortutako gainazal berrien irudietan eta, horretaz gain, hori kobalenteki eta elektrostatikoki lotzen denean, batez besteko gainazalaren zimurtasunaren jaitsiera ere behatzen da. Beraz, kitosanoak filmaren gainazala leuntzen duela esan daiteke. Gainera, argazki kobalente eta elektrostatikoei erreparatuz, kitosanoa hidrolizatutako zonaldean soilik txertatzen dela beha daiteke hidrolizatu gabeko gainazala osorik bereizten jarraitzen baita. Berez hidrolisiaren ondoren sortutako barrunbeak kitosanoak partzialki estaltzen ditu azken gainazal horien $\mathrm{R}_{\mathrm{a}}$ txikituz (9. irudia).

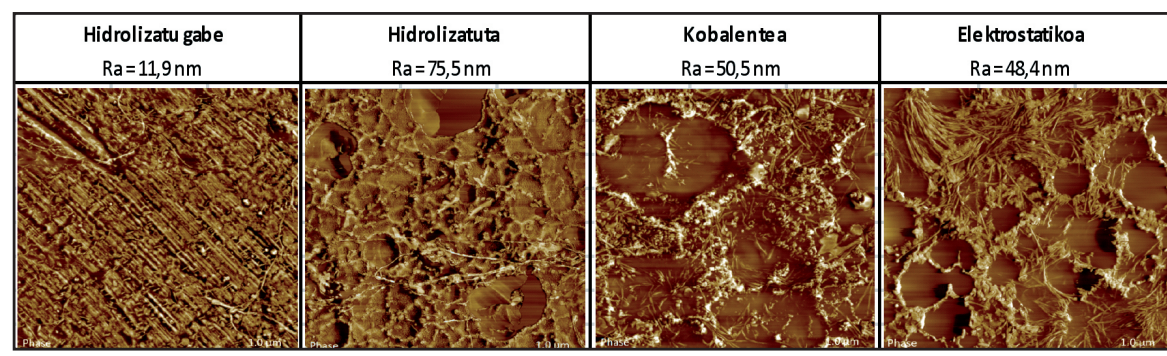

9. irudia. AFM-aren bidez lortutako PLLA-ZnO gainazalen topografien irudiak. 
Elikagaien paketatze aktiborako polimeroen gainazalaren aldaketa

\section{ONDORIOAK}

Polimeroen gainazala eraldatzeak abantaila handiak ekar ditzake paketatze-material moduan erabiltzeko orduan, hala nola, janaria hondatu barik gehiago irauteko gaitasuna, gainazalen bakterioen aurkako portaera areagotzen denean. PLLA paketatze-industriarako oso interesgarria den polimero biodegradagarria da. PLLA-k gainazalaren eraldaketa jasan ahal du modu egokian, bai kobalenteki, bai elektrostatikoki, bakterioen aurkako biopolimero ezaguna den kitosanoarekin. Lan honetan, bakterioen aurkako ezaugarri hobetuak izan daitezkeen material polimerikoak arrakastaz eratu dira helburu horretarako espezifikoki diseinatutako aldaketa-estrategiaren konbinaketa egokiaren bitartez.

\section{ESKER ONAK}

Egileek eskertzen dute FRONTIERSek, ELKARTEK programak eta IT718-13 Ikerkuntza taldeak emandako laguntza ekonomikoa eta SGIkerrek (UPV/EHU, MICINN, GV/EJ, EGEF eta EGIF) emandako laguntza teknikoa eta gizatiarra eskertzen dute.

\section{BIBLIOGRAFIA}

[1] THARANATHAN, R.N. 2003. «Biodegradable films and composite coatings: past, present and future». Trends Food Sci. Technol., 14, 71-78.

[2] THOMPSON, R.C.; MOORE, C.J.; VOM SAAL, F.S.; SWAN, S. H. 2009. «Plastics, the environment and human health: current consensus and future trends». Philos. Trans. R. Soc. Lond. B. Biol. Sci., 364, 2153-2166.

[3] AVELLA, M.; BONADIES, E.; MARTUSCELLI, E.; RIMEDIO, R. 2001. «European current standardization for plastic packaging recoverable through composting and biodegradation». Polym. Test., 20, 517-521.

[4] CORAÇA, D.C.; DUEK, E.A.R.; PADOVANI, C.A.; CAMILLI, J.A. 2008. «Osteointegration of poly(L-lactic acid)PLLA and poly(L-lactic acid)PLLA/ poly(ethylene oxide)PEO implants in rat tibiae».J. Mater. Sci. Mater. Med., 19, 2699-2704.

[5] LIM, L.T.; AURAS, R.; RUBINO, M. 2008. «Processing technologies for poly(lactic acid)».Prog. Polym. Sci., 33, 820-852.

[6] XIAO, L.; WANG, B.; YANG, G.; GAUTHIER, M. 2006. «Poly (Lactic acid)- based biomaterials: Synthesis, modification and applications». Biomed. Sci. Eng. Technol. 11, 249-282.

[7] DONLAN, R.M. 2002. «Biofilms: Microbial life on surfaces». Emerg. Infect. Dis., 8, 881-890. 
[8] SREY, S.; JAHID, I.K.; HA, S. DO. 2013. «Biofilm formation in food industries: A food safety concern». Food Control, 31, 572-585.

[9] NOSTRO, A.; SCAFFARO, R.; GINESTRA, G.; D’ARRIGO, M.; BOTTA, L.; MARINO, A.; BISIGNANO, G. 2010. «Control of biofilm formation by poly-ethylene-co-vinyl acetate films incorporating nisin». Appl. Microbiol. Biotechnol., 87, 729-737.

[10] ZHU, Y.; MAO, Z.; GAO, C. 2013. «Aminolysis-based surface modification of polyesters for biomedical applications». RSC Adv., 3, 2509-2519.

[11] BENDINGER, B.; RIJNAARTS, H.H.M.; ALTENDORF, K.; ZEHNDER, A.J.B. 1993. «Physicochemical cell surface and adhesive properties of coryneform bacteria related to the presence and chain length of mycolic acids». Appl. Environ. Microbiol., 59, 3973-3977.

[12] VERMEIREN, L.; DEVLIEGHERE, F.; VANBEEN, M.; KRUIJF, N. DE; DEBEVERE, J. 2000. «Development in the active packaging of foods». J. Food Technol. Africa, 5, 6-13.

[13] XU, J.; ZHANG, J.; GAO, W.; LIANG, H.; WANG, H.; LI, J. 2009. «Preparation of chitosan/PLA blend micro/nanofibers by electrospinning». Mater. Lett., 63, 658-660.

[14] WAN, Y.; WU, H.; YU, A.; WEN, D. 2006. «Biodegradable polylactide / chitosan blend membranes». Biomacromolecules, 7, 1362-1372.

[15] YANG, J.; BEI, J.; WANG, S. 2002. «Enhanced cell affinity of poly (D, Llactide) by combining plasma treatment with collagen anchorage». Biomaterials, 23, 2607-2614.

[16] DEL HOYO, S.; PÉREZ, L.; GÓMEZ, F.; LIZUNDIA, E.; KURITKA, I.; SEDLARIK, V.; LAZA, J.M.; VILAS, J.L. 2016. «Construction of antibacterial poly ( ethylene terephthalate) films via layer by layer assembly of chitosan and hyaluronic acid». Carbohydr. Polym., 143, 35-43.

[17] GODDARD, J.M.; HOTCHKISS, J.H. 2007. «Polymer surface modification for the attachment of bioactive compounds». Prog. Polym. Sci., 32, 698-725.

[18] ZHU, Y.; GAO, C.; LIU, X.; SHEN, J. 2002. «Surface modification of polycaprolactone membrane via aminolysis and biomacromolecule immovilization for promoting cytocompatibility of human endothelial cells». Biomacromolecules, 3, 1312-1319.

[19] THAM, C.Y.; ABDUL HAMID, Z.A.; AHMAD, Z.; ISMAIL, H. 2014. «Surface modification of poly(lactic acid) (PLA) via alkaline hydrolysis degradation». Adv. Mater. Res., 970, 324-327.

[20] LIZUNDIA, E.; RUIZ-RUBIO, L.; VILAS, J.L.; LEÓN, L.M. 2016. «Poly(l-lactide)/ZnO nanocomposites as efficient UV-shielding coatings for packaging applications». J. Appl. Polym. Sci., 133, 42426-42433.

[21] LLORENS, A.; LLORET, E.; PICOUET, P.A.; TRBOJEVICH, R.; FERNANDEZ, A. 2012. «Metallic-based micro and nanocomposites in food contact materials and active food packaging». Trends Food Sci. Technol., 24, 19-29. 
Elikagaien paketatze aktiborako polimeroen gainazalaren aldaketa

[22] AHMAD, M. BIN; JOKAR, M. 2010. «Silver/poly (lactic acid) nanocomposites: preparation, characterization and antibacterial activity». Int. J. Nanomedicine, 5, 573-579.

[23] REN, G.; HU, D.; CHENG, E.W.C.; VARGAS-REUS, M.A.; REIP, P.; ALLAKER, R.P. 2009. «Characterisation of copper oxide nanoparticles for antimicrobial applications». Int. J. Antimicrob. Agents, 33, 587-590.

[24] PANTANI, R.; GORRASI, G.; VIGLIOTTA, G.; MURARIU, M.; DUBOIS, P. 2013. «PLA-ZnO nanocomposite films: Water vapor barrier properties and specific end-use characteristics». Eur. Polym. J., 49, 3471-3482.

[25] DE SILVA, R.T.; PASBAKHSH, P.; SUI, L.; YOONG, A. 2015. «ZnO deposited/encapsulated halloysite-poly(lactic acid) (PLA) nanocomposites for high performance packaging films with improved mechanical and antimicrobial properties». Appl. Clay Sci., 111, 10-20.

[26] XIE, Y.; HE, Y.; IRWIN, P.L.; JIN, T.; SHI, X. 2011. «Antibacterial activity and mechanism of action of zinc oxide nanoparticles against Campylobacter jejuni». Appl. Environ. Microbiol., 77, 2325-2331.

[27] AIDER, M. 2010. «Chitosan application for active bio-based films production and potential in the food industry: Review». LWT - Food Sci. Technol., 43, 837-842.

[28] MURATA, H.; KOEPSEL, R.R.; MATYJASZEWSKI, K.; RUSSELL, A.J. 2007. «Permanent, non-leaching antibacterial surfaces-2: How high density cationic surfaces kill bacterial cells». Biomaterials, 28, 4870-4879.

[29] OUATTARA, B.; SIMARD, R.E.; PIETTE, G.; BÉGIN, A.; HOLLEY, R.A. 2000. «Diffusion of acetic and propionic acids from chitosan-based antimicrobial packaging films». Journal of Food Science, 65, 768-773.

[30] LAO, L.; TAN, H.; WANG, Y.; GAO, C. 2008. «Chitosan modified poly(Llactide) microspheres as cell microcarriers for cartilage tissue engineering». Colloids Surf. B. Biointerfaces, 66, 218-225.

[31] CUI, Y.L.; DI QI, A.; WANG LIU, W.; HUI WANG, X.; WANG, H.; MING MA, D.; DE YAO, K. 2003. «Biomimetic surface modification of poly(L-lactic acid) with chitosan and its effects on articular chondrocytes in vitro». Biomaterials, 24, 3859-3868.

[32] CHOllet, C.; CHANSEAU, C.; BROUIllaud, B.; DURRIEU, M.C. 2007. «RGD peptides grafting onto poly(ethylene terephthalate) with well controlled densities». Biomolecular Engineering, 24, 477-482.

[33] NOEL, S.; LIBERELLE, B.; ROBITAILlE, L.; DE CRESCENZO, G. 2011. "Quantification of primary amine groups available for subsequent biofunctionalization of polymer surfaces». Bioconjug. Chem., 22, 16901699.

[34] KERTÉSZ SZ, T.B.; DE FREITAS, HODÚR C. 2014. «Characterization of Polymer Membranes By Contact Angle Goniometer». Analecta, 8, 18-22.

[35] MAGONOV S.N.; RENEKER D.H. 1997. «Characterization of polymer surfaces with Atomic Force Microscopy». Annual Review of Materials Science, 27, 175-222. 
[36] CROLL, T.I.; O'CONNOR, A.J.; STEVENS, G.W.; COOPER-WHITE, J.J. 2004. «Controllable surface modification of poly(lactic-co-glycolic acid) (PLGA) by hydrolysis or aminolysis I: physical, chemical, and theoretical aspects». Biomacromolecules, 5, 463-473.

[37] TSUJI, H.; ISHIDA, T. 2002. «Poly(l-lactide). X. Enhanced surface hydrophilicity and chain-scission mechanisms of poly(L-lactide) film in enzymatic, alkaline, and phosphate-buffered solutions». J. Appl. Polym. Sci., 87, 1628-1633.

[38] STAROS, J.V.; WRIGHT, R.W.; SWINGLE, D.M. 1986. «Enhancement by N-hydroxysulfosuccinimide of water-soluble carbodiimide-mediated coupling reactions». Analytical Biochemistry, 156, 220-222.

[39] PREGO, C.; TORRES, D.; FERNANDEZ-MEGIA, E.; NOVOA-CARBALLAL, R.; QUIÑOA, E.; ALONSO, M.J. 2006. «Chitosan-PEG nanocapsules as new carriers for oral peptide delivery: Effect of chitosan pegylation degree». Journal of Controlled Release, 111, 299-308. 